\title{
Oroquieta City Households' Willingness to Pay for Coastal Biodiversity Conservation
}

\author{
Julie Carl P. Ureta ${ }^{1}$, Rodel D. Lasco ${ }^{2}$, Asa Jose U. Sajise ${ }^{3} \&$ Margaret Mejorada Calderon $^{4}$ \\ ${ }^{1}$ School of Environmental Science and Management (SESAM), University of the Philippines-Los Baños, Los \\ Baños, Laguna, Philippines \\ ${ }^{2}$ World Agroforestry Centre (ICRAF), Los Baños, Laguna, Philippines \\ ${ }^{3}$ College of Economics and Management (CEM), University of the Philippines-Los Baños, Los Baños, Laguna, \\ Philippines \\ ${ }^{4}$ College of Forestry and Natural Resources (CFNR), University of the Philippines-Los Baños, Los Baños, \\ Laguna, Philippines \\ Correspondence: Julie Carl P. Ureta, School of Environmental Science and Management (SESAM), University \\ of the Philippines-Los Baños, Los Baños, Laguna, Philippines. Tel: 63-915-967-0356. E-mail: \\ carlureta@gmail.com
}

Received: November 27, 2013 Accepted: August 5, 2014 Online Published: September 24, 2014

doi:10.5539/jsd.v7n5p82 URL: http://dx.doi.org/10.5539/jsd.v7n5p82

\begin{abstract}
Over the years, ecosystem services have been undervalued since regarded as public good. Low appreciation on the benefits provided by the ecosystem has led to the overutilization of resources, causing negative impacts to biodiversity and environment. In the Philippines, biodiversity conservation has not been given enough priority, and has been beset with various problems such as insufficient funding. This usually applies in coastal communities, where majority of community members have low capacity to contribute monetarily. However, the rising occurrence of climate-related phenomena also increases the awareness of communities and their willingness to contribute to environmental conservation activities such as Payments for Ecosystem Services (PES). This study aimed to value the coastal conservation activities from households of Oroquieta City through contingent valuation method. The computed mean willingness to pay for coastal conservation using parametric estimation was $\mathrm{PhP} 30.39$, wherein the estimated mean willingness to pay translates to $0.23 \%$ of their average income. Potential revenue to be collected annually could amount to PhP 1.8 million. In five years, the total collection could reach PhP 9 million, which is also substantial to make the biodiversity conservation activities sustainable. The estimation of this study could serve as basis for implementation of PES in the the coastal communities for sustainable biodiversity conservation.
\end{abstract}

Keywords: coastal biodiversity conservation, natural resource economics, payments for ecosystem services (PES), valuation, willingness to pay

\section{Introduction}

Ecosystem services are usually valued only through its direct use or the provisioning services. Other types of services such as supporting, regulating and cultural are often less appreciated and undervalued. Undervaluation of the ecosystem tends to lead to faster degradation compared to rate of ecosystem recovery. Due to the rapid global development, ecosystem services which were previously provided by nature for free are becoming scarcer (Wunder, 2005). This insight gave rise to the concept of payments for ecosystem services (PES) which recognizes the trade off of using the ecosystem services with corresponding compensation. Increasing economic development pushes the ecosystem services into critical state while biodiversity conservation efforts are not catching up with the markets' exploitation of resource.

The Philippines is one of the megadiversity countries in the world. Unfortunately, the country is also one of world's top biodiversity hotspot due to increasing human population, resource demand, habitat destruction and unsustainable development (Jabines \& Inventor, 2007). The country is also the $11^{\text {th }}$ top producing fish country in the world therefore Filipinos are highly dependent in the coastal ecosystem (Food and Agriculture Organization [FAO], 2012). Although there have been efforts to conserve biodiversity in the country, the cost of biodiversity 
conservation is not sustainable without continuous financing provision and community-based involvement. Same goes true particularly for coastal ecosystems and biodiversity.

Payment for ecosystem services (PES) is an emerging scheme attempting to promote sustainable financing for continuous biodiversity conservation in an area. Traditional financing sources from grants and national budget allocation do not suffice to sustain effective management of resources (Lasmarias, 2012). Promoting sustainable conservation to the communities has tradeoffs that should be considered. The community will not engage to such conservation activities if they do not see the incentive they could have. PES promises a plow back of financial resources to sustain conservation efforts of communities and an opportunity for poverty reduction since conservation activities will be treated as income generating potential (Lasmarias, 2012). Borges' (2011) definition of PES still follows Wunders' (2005) 5 principles: 1) voluntary transaction; 2) well-defined environmental service; 3 ) there is at least one ES buyer; 4) there is a minimum of one ES provider; and 5) if and only if the provider continues to supply the ecosystem service (Borges, 2011). The framework of the PES suggests that the recipient of the ecosystem service should support the providers who continuously supply and maintain the services. The support that the recipients provide should compensate for the service of the supplier for maintaining the ecosystem. In this way, PES could protect the ecosystem since it would encourage providers to conserve rather than to extract it for utilization.

Several attempts in the Philippines were already made to establish PES. For instance, in Balian watershed, downstream residents negotiated with private owners upstream to plant trees as part of watershed conservation in exchange for protecting these private lands from illegal encroachment. Downstream residents mobilized a group for monitoring and patrolling the land (Padilla, Tongson, \& Lasco, 2005). Meanwhile, La Tondeña Distillery in Mt. Kanlaon also benefited from a PES arrangement with local communities. In order for the company to have a sustainable source of water, it engaged the local communities for reforestation and rehabilitation activities. In exchange, the company trained the communities in agroforestry farming practices (Padilla et al., 2005). On the other hand, in the study of Amponin (2008) on Peñablanca Landscape and Seascape in Cagayan, a portion of tourism fees collected by the operators are provided to upland communities for the protection of the watershed as payments (Lasmarias, 2012). Another case of PES is on the Maasin Watershed in Iloilo wherein the Metro Iloilo Water District made payments to local government for the watershed protection (Alli \& Oliva, 2001). Shortly, the payments were transferred to the Department of Environment and Natural Resources. Often PES takes place for watershed management; however since coastal ecosystem services are equivalently important, marine and coastal PES have begun to develop beginning with coastal ecosystem service valuation.

Valuation methodologies were used since 1960's in an attempt to put value on environmental goods and services (Carson, et. al., 2001). Different valuation techniques could be applied in PES studies depending on the ecosystem service catered. One of these techniques is the contingent valuation method (CVM) which is a valuation technique that ellicits the preference stated by respondents to quantify their willingness-to-pay (WTP) for an environmental good or service (Wedgwood \& Sansom, 2003). Several studies in the Philippines have been conducted using the contingent valuation methodology. In 2005, Calderon et al. estimated water user fees for the households of Metro Manila (Calderon et al, 2005). Similarly in 2007, Amponin et al. estimated the willingness to pay of domestic water users for watershed protection in Tuguegarao City (Amponin, Bennagen, Hess, \& Dela Cruz, 2007). For coastal ecosystems, estimated value of biodiversity by Arin \& Kramer (2002) was derived from average willingness to pay on entrance fees from tourists (Samonte et al., 2007). In other countries, WTP was also used in valuing coastal tourism management (S. Birdir, Unal, K. Birdir, \& Williams, 2013). Valuation of ecosystem services is an important aspect for establishing payments for ecosystem services. The technique provides a quantified value on how much the communities are willing to pay for biodiversity conservation efforts which could eventually be the basis for fee collections in the implementation of PES in the Layawan watershed.

The paper discusses the value of the coastal conservation activities in Oroquieta City as part of Iligan Bay. Specifically, the paper evaluates the knowledge and perception of Oroquieta City households about the importance of biodiversity conservation in the area. The paper also statistically identifies specific factors affecting their decision to engage in coastal conservation activities and estimates their willingness to pay through contingent valuation methodology. 


\section{Method}

\subsection{Study Site}

Oroquieta City is located in Northern Mindanao as a capital of the Province of Misamis Occidental. The total land area of the city is 26393.46 hectares with an estimated population of 65165 since 2006 (City Government of Oroquieta, 2010).

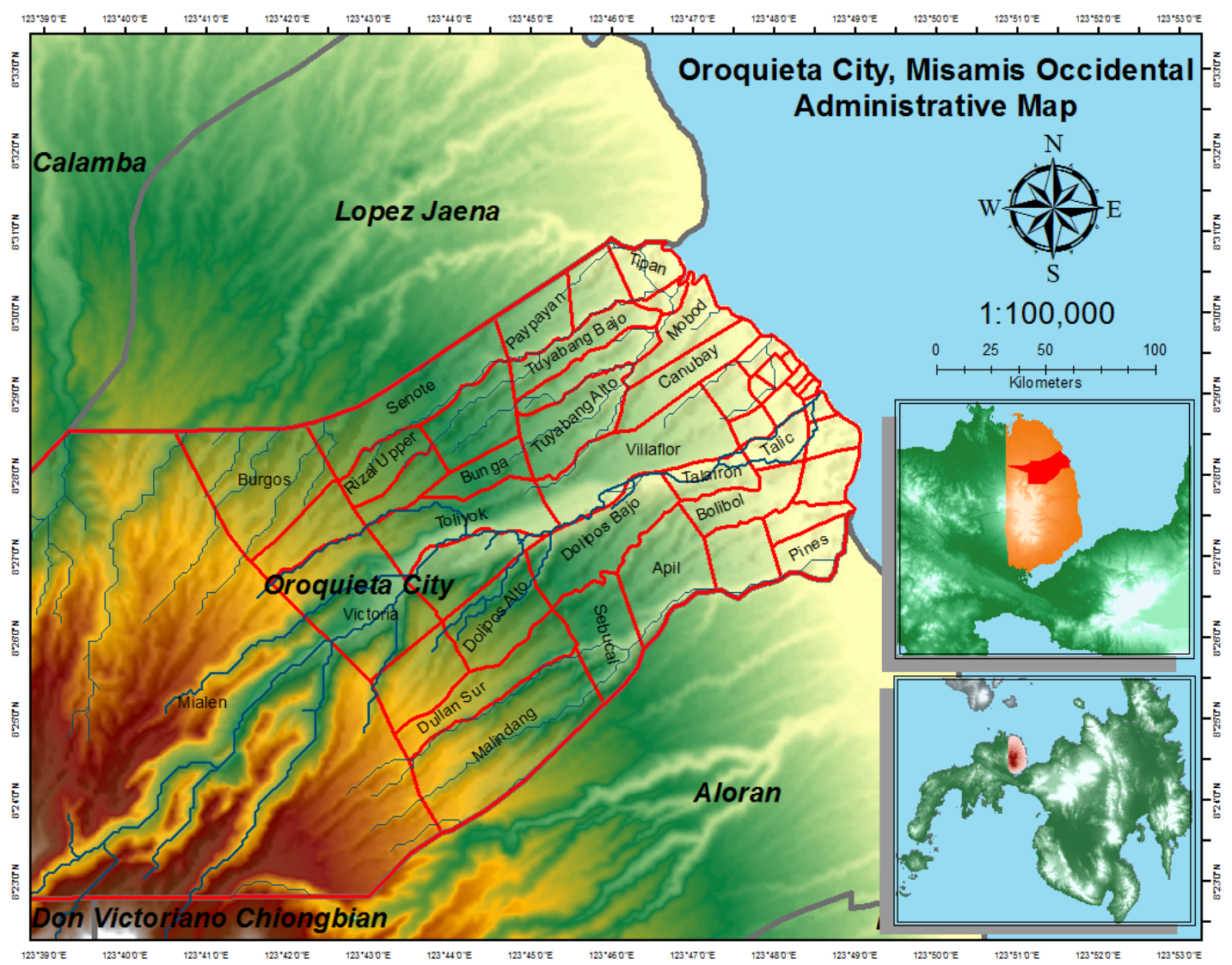

Figure 1. Location map of Oroquieta City, Misamis Occidental

The Layawan River, which is still one of the cleanest rivers in the country until the present time, establishes the ridge to reef connection of Mt. Malindang Range Natural Park to the coastlines of Oroquieta City towards Iligan Bay. Oroquieta City households heavily rely on both Mt. Malindang Range Natural Park and Iligan Bay's ecosystem services. Oroquieta City residents also rely in the Layawan watershed for their daily source of useable water.

\subsection{Sampling Procedures}

Simple random sampling was conducted to determine 300 sample households to be included in the survey. These households were randomly selected from the list of residents availing the service of Oroquieta City Water District (OCWD). Although a total number of 300 households were actually interviewed, only 277 respondent data were successfully processed. The decrease was due to: a) Portion of the targeted respondents were considered part of the pre-test to validate the effectivity of the survey questionnaire and finalize the set bid amounts; b) Data which lacks substantial responses due to difficulty in terms of providing answers in the interview were considered "bad data".

\subsection{Survey}

The questionnaire was split into four sections. The first section basically elicited information regarding the baseline information of the respondents in terms of awareness on ecosystem services, ecosystem interconnectivity, and current issues and threats. This part also includes perception survey in terms of willingness to participate in potential future conservation activities and acceptability of environmental protection and expansion projects. The second section of the questionnaire explains the status quo of issues, problems, and 
threats to the ecosystem and natural resources. After the explanation on issues, the enumerator presents the Payments for Ecosystem services program framework which will be the recipient of the communities' value for coastal conservation activities. The framework was followed by explaining the proposed conservation activities in multicolored images together with the future benefits that the respondents would get from the ecosystem. The third section of the questionnaire mainly contains the contingent valuation scenario for the households. At this point, the assumptions were clearly explained by the enumerators to answer the contingent valuation elicitation questions. The question for eliciting the respondents' willingness to pay will be in a referendum format where they will vote yes or no when asked to support the conversation program if it will cost a certain bid amount or price to be added in their water bill for the next 5 years. The payment vehicle used was water bill for ease of payment collection and has direct relationship to the ecosystem through the mangrove ecosystem services. Finally, the fourth section was intended to capture the demographic and socio-economic profile of the household as part of the factors that affects their decision.

An enumerators' training session was conducted prior to the survey to ensure understanding of the purpose of the study and the method. A pre-test was done to validate the soundness of the questionnaire and determine the bid amounts.

\subsection{Bid Amounts}

The study made use of dichotomous choice format where respondents were asked with questions answerable by YES or NO. CV question was also dichotomous in the form of a referendum. The final bid amounts were set to $10,50,100,150$, and 200 per month as an addition to their current water bill.

\subsection{Data Analysis}

The results of the survey were subjected to statistical analysis and applied to econometric models to estimate the willingness to pay of the respondents as value for the conservation activities. Logit regression modelling technique was used in order to determine the factors that significantly affect the decisions of the respondents in determining their willingness to pay for the conservation activities.

\section{Results}

\subsection{Socioeconomic Profile of Respondents}

The survey only interviewed household heads or household members that are capable to decide financially for the household. On the average, household heads are aged 50 years old.

Around $60 \%$ of the total respondents are female and $40 \%$ were male. Probable reason for the dominance of females as respondents is due to the time the interview was conducted. Males are usually at work at the time the interview was conducted. Among the respondents $23 \%$ are employed locally and $8 \%$ were employed by the government. Self-employed respondents consist of $27 \%$ while unemployed respondents consist of $35 \%$ of the total sample. The remaining $7 \%$ rely on pensions and remittances from OFW family members. Around $8 \%$ of the total samples have secondary occupation apart from their main source of income.

Data on educational attainment showed that $24 \%$ of the respondents reached primary level of education, $45 \%$ reached secondary level, and $15 \%$ reached tertiary level of education. A $12 \%$ fraction of the respondents have no educational attainment at all and $4 \%$ of the respondents reached post tertiary level. The average household consists of 4 persons per household. The average household income obtained was PhP 13 059.52. According to Virola (2011), at the national level, the family of five needed PhP 4869.00 monthly income to sustain food for the household and PhP 7017.00 to stay out of poverty. Specifically for Region X, a family of five needed $\mathrm{PhP} 11$ 543.00 to sustain food for the household and PhP 16568.00 monthly income to stay out of poverty (Virola, 2011). On the average, the household income of the respondents of the study is above the national poverty threshold. However, on the regional level, the average household income of the respondents is only enough to sustain food for the family but still below the poverty threshold of the region.

\subsection{Awareness and Perception on Interconnected Ecosystem Services}

Baseline information regarding awareness and perception of the respondents towards ecosystem services and ecosystem's interconnected impact were elicited in the survey questionnaire.

A large amount of the respondents (83\%) are aware of Mt. Malindang Range Natural Park. In addition, $65 \%$ are aware on the meaning of a watershed. Majority (94\%) of the respondents are aware of the different ecosystem services that they get from Mt. Malindang and other nearby ecosystems. Most respondents (93\%) also noted that mangrove ecosystem and mangrove forest is also important to the community and the environment as a whole.

The respondents were also asked on their experience of the negative effects of some issues existing within the 
community. A large fraction of the respondents $(81 \%)$ mentioned to have experienced negative effects from upland due to farming, particularly due to the chemical substances that agricultural areas used for fertilization. Large number of respondents $(70 \%)$ also experiences negative effects due to domestic waste disposal. This is more observable in areas near the river, streams, and creeks until the coastlines. In terms of livestock-raising, $77 \%$ of the respondents confirmed that they experience negative effects. This could be associated to waste carried by the waters particularly during rainy seasons. Noticeably, majority of the respondents (78\%) confirmed that they experience negative effects from upland due to quarrying activities, particularly in some portion of the river bed and river banks located on the upland area.

Generally, the residents have high awareness towards their environment and the interconnectivity of the ecosystems. Respondents' high awareness could be attributed to series of events happened in the community brought by environmental factors such as typhoon damages, flooding occurrence, and storm surges. Oroquieta City is also strategically located across Iligan and Cagayan de Oro City which incurred heavy damages from climate related events.

\subsection{Factors Affecting the Willingness to Pay of Respondents to Conservation Activities}

Prior to the estimation of the willingness to pay, the study also identified the significant factors that affect the respondents' willingness to participate in conservation activities. Without any restriction of amount for contribution, out of the 277 respondents, 267 or $96 \%$ said that they are willing to participate in the conservation activities. However, this statistics is expected to change if a certain restriction or constraint is already in effect, such as specific activity for conservation and amount of contribution.

The estimated mean willingness to pay were subjected to two scenarios: 1) Analysis of willingness to pay including all respondent households (uncensored); and 2) Analysis of willingness to pay of all respondent households excluding uncertain WTP votes (censored).

\subsubsection{Uncensored Estimate of Willingness to Pay}

The first scenario simulates the situation wherein all households in the community are included in the conservation fund contribution whether certain or not on the decision in the survey. This would simulate a mandatory payment scenario for households of Oroquieta City which are financially capabe to contribute.

Table 1. Significant factors affecting the willingness to pay (uncensored)

\begin{tabular}{lcccc}
\hline VARIABLE & COEFFICIENT & $\begin{array}{c}\text { P-VALUE } \\
\text { (SIGNIFICANCE OF } \\
\text { COEFFICIENT) }\end{array}$ & $\begin{array}{c}\text { MARGINAL } \\
\text { EFFECTS } \\
\text { DX/DY }\end{array}$ & $\begin{array}{c}\text { P-VALUE } \\
\text { (SIGNIFICANCE OF } \\
\text { MARGINAL } \\
\text { EFFECTS) }\end{array}$ \\
\hline Bid Amount & -0.0248382 & $0.000^{* * *}$ & -0.0039238 & 0.000 \\
Household size & 0.4324305 & $0.000^{* * *}$ & 0.0683129 & 0.000 \\
\hline
\end{tabular}

$\mathrm{LR} \mathrm{Chi}^{2}=103.71 ;$ Prob $>\mathrm{Chi}^{2}=0.0000 * * *=$ significant at $1 \%$

The logit regression analysis showed only the Bid Amount and Household size pose a significant contribution to the households' willingness to pay.

The Bid Amount or the additional amount to be included in their water bill for funding the conservation activities poses a significant negative relationship with the respondents' willingness to pay. This indicates that as the Bid Amount increases by 1 unit, the respondents' willingness to pay also decreases by the marginal effect of $0.3 \%$. This represents as the price of the coastal conservation activity per individual. The result is consistent with the law of demand wherein as the price increases, the quantity being demanded of that good decrease in return. The result of the logit coefficient is statistically significant with confidence of $99 \%$ which implies that the bid amount highly affects the decision of the respondents.

Also, the number of people in the household or household size affects the willingness to pay of the respondent positively. At $99 \%$ level of confidence, as the household size increases, the probability that the respondent is also willing to pay increases by $6.8 \%$. This implies that households recognize the fact that more members also mean more extraction of resource and also increases contribution to environmental degradation.

The study made use of both parametric and non-parametric estimation of the mean willingness to pay. 
Table 2. Summary of mean willingness to pay (uncensored)

\begin{tabular}{|c|c|c|c|c|c|c|c|c|}
\hline \multirow{2}{*}{$\begin{array}{c}\text { CONSERVATION } \\
\text { ACTIVITY }\end{array}$} & \multicolumn{3}{|c|}{ PARAMETRIC ESTIMATION } & \multicolumn{3}{|c|}{$\begin{array}{l}\text { NON-PARAMETRIC } \\
\text { ESTIMATION }\end{array}$} & \multirow{2}{*}{$\begin{array}{c}\text { TOTAL } \\
\text { \# OF } \\
\text { RESP }\end{array}$} & \multirow{2}{*}{$\begin{array}{c}\text { TOTAL\# } \\
\text { OF RESP } \\
\text { WHO ARE } \\
\text { WILLING } \\
\text { TO PAY }\end{array}$} \\
\hline & $\begin{array}{l}\text { Mean } \\
\text { WTP }\end{array}$ & $\begin{array}{c}\text { CI } \\
(95 \%)\end{array}$ & $\begin{array}{c}\text { Stan. } \\
\text { Err }\end{array}$ & $\begin{array}{c}\text { Min } \\
\text { WTP }\end{array}$ & $\begin{array}{l}\text { Max } \\
\text { WTP }\end{array}$ & $\begin{array}{l}\text { Mean } \\
\text { WTP }\end{array}$ & & \\
\hline Coastal & 30.39 & $\begin{array}{l}24.43- \\
36.35\end{array}$ & 3.03 & 38.73 & 62.89 & 50.81 & 277 & 84 \\
\hline
\end{tabular}

Summary shows that mean willingness to pay thruogh parametric estimation of coastal conservation activities is $\mathrm{PhP} 30.39$ wherein at $95 \%$ level of confidence, the range of the respondents' willingness to pay is within $\mathrm{PhP}$ 24.43 - PhP 36.35. The non-parametric estimation shows the respondents' mean willingness to pay lies within the range of $\mathrm{PhP} 38.73$ to $\mathrm{PhP} 62.89$. On the average, the willingness to pay of respondents to coastal conservation is computed to be PhP 50.81.

The parametric estimate was conducted from the logit regression model to compute for the estimated mean willingness to pay of the respondents for contributing to the conservation activities.

$$
\operatorname{Pr}(\mathrm{Y}=1)=\alpha+\beta_{0}+\beta_{\mathrm{i}} \mathrm{X}_{\mathrm{i}}
$$

Applying the significant factors of the logit model to predict estimate:

$$
\operatorname{logit}\left(\mathrm{Y}^{*}=1\right) \quad=-2.294353-0.024838 \text { 2BidAmount }+0.432430 \text { 5HHsize }
$$

The predicted $\mathrm{Y}^{*}$ would be an input to the equation to compute for the parametric mean willingness to pay of each respondent.

$$
\begin{gathered}
\text { WTPhat }=1 *\left[\left(\mathrm{Y}^{*}-\beta(\text { BidAmount }) * \text { BidAmount }\right) / \beta(\text { Bidamount })\right] \\
\text { WTP }=\frac{\text { MWTP }}{\mathrm{N}}
\end{gathered}
$$

Computing for the mean willingness to pay (WTP*) of respondents for Coastal conservation activities:

$$
\mathrm{WTP}_{\text {Coastal }}=\frac{8314.659816}{277}=30.02
$$

On the non-parametric estimation, the study employed a Turnbull estimation method to compute for the respondents' willingness to pay. The Turnbull estimation makes use of the demand curve created from the cumulative frequency of respondents who voted YES in a specific bid amount. The estimated mean willingness to pay of respondents will be the average of values in the area below the computed demand curve.

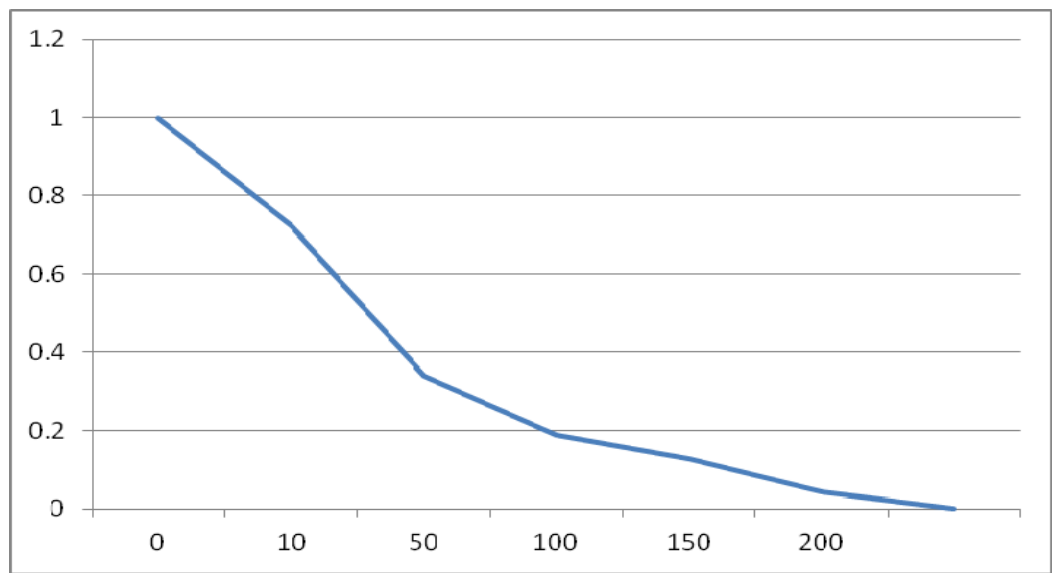

Figure 2. Cumulative frequency of YES votes for coastal conservation activities (uncensored)

$$
(\mathrm{x}=\text { Bid Amount; } \mathrm{y}=\text { percentage })
$$

The computation of the demand curve for the respondents' mean willingness to pay is presented in Table 3 . 
Table 3. Summary of values for respondents who agreed to coastal conservation activities (uncensored)

\begin{tabular}{|c|c|c|c|c|c|}
\hline $\begin{array}{c}\text { BID } \\
\text { AMOUNT }\end{array}$ & $\begin{array}{c}\text { TOTAL } \\
\text { SAMPLES }\end{array}$ & $\begin{array}{c}\text { TOTAL } \\
\text { NUMBER OF } \\
\text { SAMPLES } \\
\text { THAT } \\
\text { ANSWERED } \\
\text { YES }\end{array}$ & $\begin{array}{c}\text { PERCENTAGE } \\
\text { OF "YES" } \\
\text { RESPONSES } \\
(\%)\end{array}$ & $\begin{array}{c}\text { LOWER } \\
\text { BOUND } \\
\text { WILLINGNESS } \\
\text { TO PAY } \\
\text { VALUES }\end{array}$ & $\begin{array}{c}\text { UPPER BOUND } \\
\text { WILLINGNESS } \\
\text { TO PAY }\end{array}$ \\
\hline 10 & 61 & 44 & 72 & 2.79 & 3.83 \\
\hline 50 & 62 & 21 & 34 & 19.13 & 7.50 \\
\hline 100 & 53 & 10 & 19 & 15.00 & 6.14 \\
\hline 150 & 55 & 7 & 13 & 9.21 & 12.57 \\
\hline 200 & 46 & 2 & 4 & 16.76 & 8.70 \\
\hline Total & 277 & 84 & -- & 62.89 & 38.73 \\
\hline Mean WTP & & & & \multicolumn{2}{|c|}{50.81} \\
\hline
\end{tabular}

Results show that the minimum mean willingness to pay of respondents for coastal conservation activities is $\mathrm{PhP}$ 38.73 while the maximum mean willingness to pay is $\mathrm{PhP}$ 62.89. The overall average of the respondents' willingness to pay is $\mathrm{PhP} 50.81$.

3.3.2 Censored estimate of Willingness to Pay

The second scenario is a modification of the first scenario by taking out the respondents who voted for YES but were unsure of their answers. This simulates a voluntary contribution of households to conservation activities.

Table 4. Significant factors affecting the willingness to pay (censored)

\begin{tabular}{lcccc}
\hline VARIABLE & COEFFICIENT & $\begin{array}{c}\text { P-VALUE } \\
\text { (SIGNIFICANCE OF } \\
\text { COEFFICIENT) }\end{array}$ & $\begin{array}{c}\text { MARGINAL } \\
\text { EFFECTS } \\
\text { DX/DY }\end{array}$ & $\begin{array}{c}\text { P-VALUE } \\
\text { (SIGNIFICANCE OF } \\
\text { MARGINAL } \\
\text { EFFECTS) }\end{array}$ \\
\hline Bid Amount & -0.0242769 & $0.000^{* * *}$ & -0.0035215 & 0.000 \\
Household size & 0.4649744 & $0.000^{* * *}$ & 0.0674474 & 0.000 \\
\hline
\end{tabular}

$\mathrm{LR} \mathrm{Chi}^{2}=98.32 ;$ Prob $>\mathrm{Chi}^{2}=0.0000^{* * *}=$ significant at $1 \%$

Analysis of the censored dataset of households' willingness to pay yielded the same significant variables with the uncensored dataset. Variables Bid Amount and Household Size still poses significant contribution to the respondent's willingness to pay.

The result of the parametric and non-parametric estimate of the mean willingness to pay for scenario 2 is presented in Table 5.

Table 5. Mean willingness to pay for conservation activities (censored)

\begin{tabular}{|c|c|c|c|c|c|c|c|c|}
\hline \multirow{2}{*}{$\begin{array}{c}\text { CONSERVATION } \\
\text { ACTIVITIES PER } \\
\text { CATEGORY }\end{array}$} & \multicolumn{3}{|c|}{$\begin{array}{l}\text { PARAMETRIC } \\
\text { ESTIMATION }\end{array}$} & \multicolumn{3}{|c|}{$\begin{array}{c}\text { NON-PARAMETRIC } \\
\text { ESTIMATION }\end{array}$} & \multirow{2}{*}{$\begin{array}{c}\text { TOTAL } \\
\text { \# OF } \\
\text { RESP }\end{array}$} & \multirow{2}{*}{$\begin{array}{c}\text { TOTAL \# } \\
\text { OF RESP } \\
\text { WHO ARE } \\
\text { WILLING } \\
\text { TO PAY }\end{array}$} \\
\hline & $\begin{array}{l}\text { Mean } \\
\text { WTP }\end{array}$ & $\begin{array}{c}\text { CI } \\
(95 \%)\end{array}$ & $\begin{array}{c}\text { Stan. } \\
\text { Err }\end{array}$ & $\begin{array}{c}\text { Min } \\
\text { WTP }\end{array}$ & $\begin{array}{l}\text { Max } \\
\text { WTP }\end{array}$ & $\begin{array}{l}\text { Mean } \\
\text { WTP }\end{array}$ & & \\
\hline Coastal & 24.01 & $\begin{array}{c}20.24- \\
27.80\end{array}$ & 1.92 & 35.71 & 58.23 & 46.97 & 277 & 78 \\
\hline
\end{tabular}


Summary shows that a voluntary mean willingness to pay through a parametric estimation is $\mathrm{PhP} 24.01 \mathrm{wherein}$ at $95 \%$ level of confidence, the range of the respondents' willingness to pay is within $\mathrm{PhP} 20.24-\mathrm{PhP} 27.80$. The non-parametric estimation shows the respondents' mean willingness to pay lies within the range of $\mathrm{PhP}$ 35.71 to $\mathrm{PhP} 58.28$. On the average, the willingness to pay of respondents to coastal conservation is computed to be $\mathrm{PhP} 46.97$.

Parametric estimation of the voluntary mean willingness to pay follows the same procedure as with the mandatory MWTP. Applying the significant factors of the logit model from the previous equation (1) to predict estimate:

$$
\operatorname{logit}\left(\mathrm{Y}^{*}=1\right)=-2.590792-0.024276 \text { 9BidAmount }+0.464974 \text { 4HHsize }
$$

Computing for the mean willingness to pay (WTP*) of respondents for Coastal conservation activities:

$$
\mathrm{MWTP}=\frac{6651.988691}{277}=24.01
$$

Similar to the first scenario, a demand curve was computed through the Turnbull estimation approach for the non-parametric computation.

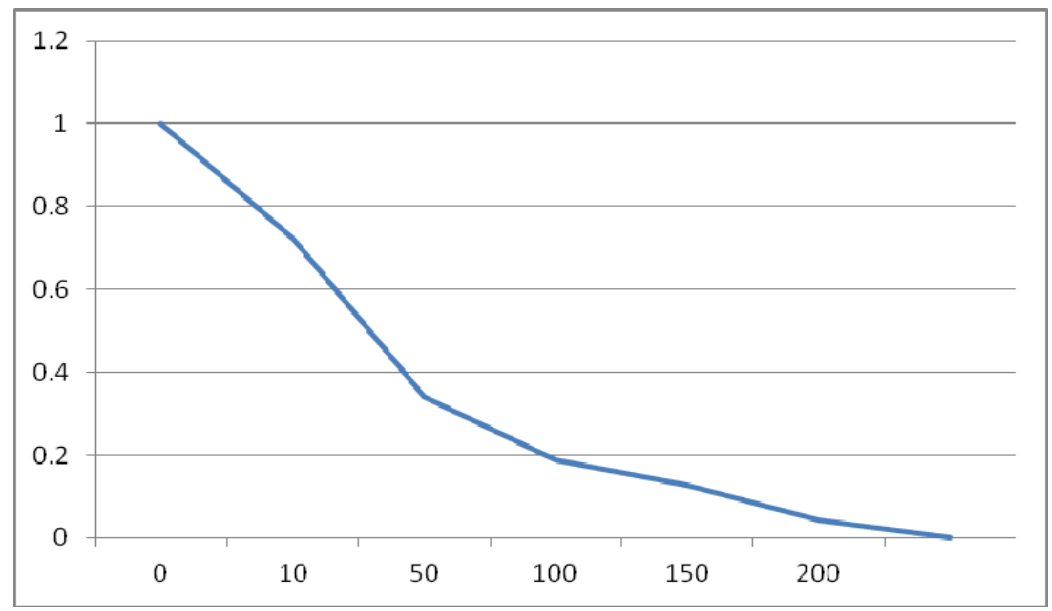

Figure 3. Cumulative frequency of YES votes for coastal conservation activities (censored)

$$
(\mathrm{x}=\text { Bid Amount; } \mathrm{y}=\text { percentage })
$$

\begin{tabular}{|c|c|c|c|c|c|}
\hline $\begin{array}{c}\text { BID } \\
\text { AMOUNT }\end{array}$ & $\begin{array}{c}\text { TOTAL } \\
\text { SAMPLES }\end{array}$ & $\begin{array}{c}\text { TOTAL } \\
\text { NUMBER OF } \\
\text { SAMPLES } \\
\text { THAT } \\
\text { ANSWERED } \\
\text { YES }\end{array}$ & $\begin{array}{c}\text { PERCENTAGE } \\
\text { OF YES } \\
\text { RESPONSES } \\
\text { FOR }(\%)\end{array}$ & $\begin{array}{c}\text { LOWER BOUND } \\
\text { WILLINGNESS } \\
\text { TO PAY VALUES }\end{array}$ & $\begin{array}{c}\text { UPPER BOUND } \\
\text { WILLINGNESS } \\
\text { TO PAY }\end{array}$ \\
\hline 10 & 61 & 41 & 67 & 3.28 & 3.50 \\
\hline 50 & 62 & 20 & 32 & 17.48 & 8.58 \\
\hline 100 & 53 & 8 & 15 & 17.16 & 2.37 \\
\hline 150 & 55 & 7 & 13 & 3.55 & 12.57 \\
\hline 200 & 46 & 2 & 4 & 16.76 & 8.70 \\
\hline Total & 277 & 78 & -- & 58.23 & 35.71 \\
\hline Mean WTP & & & & \multicolumn{2}{|c|}{46.97} \\
\hline
\end{tabular}

Similar computation of values was done to obtain the Turnbull estimates for scenario 2 (censored).

Table 6. Summary of values for respondents who agreed to coastal conservation activities (censored) 
The computation shows that the minimum mean willingness to pay of respondents for coastal conservation activities is PhP 35.71 while the maximum mean willingness to pay is $\mathrm{PhP} 58.23$. The overall average of the respondents' willingness to pay is $\mathrm{PhP} 46.97$ for Scenario 2 through non-parametric estimation method.

\subsection{Respondents' Reasons for Voting NO to the Conservation Activities}

In order to capture feedbacks from the respondents who did not agree to vote for the contribution on the conservation activities, the study elicited and tabulates the common reasons for disagreeing. Majority of the respondents did not agree to the conservation activity due to budget constraint. Respondents who do not have enough money to contribute to the conservation activities consist of $55 \%$ of the sampling population. Other reasons include: distrust in management (7.8\%); skeptic with the effectivity of the project (3.7); does not experience benefits from ecosystem services $(2.2 \%)$, and the rest with other reasons which they would not want to reveal.

As for the recommended payment vehicle, $14 \%$ of the total sample households suggested that the additional contribution should already be deducted in the income taxes. On the other hand, $18 \%$ of the total sample said that it should be included in electric bills. A small part, $1 \%$, of the total household respondents recommended the use of telephone bill as payment vehicle. Furthermore, only $2 \%$ of the total household respondents recommended the use of cell cards as payment vehicle for collecting the conservation contributions. The remaining $65 \%$ of the total household respondents still thinks that water bill is the best payment vehicle to collect the contribution for the conservation activities.

\subsection{Estimating Potential Total Annual Contribution from the Mean Willingness to Pay}

The Department of Environment and Natural Resources is allocating a budget of PhP 4million annually for the implementation of existing conservation program for the entire Mt. Malindang Range Natural Park (Manlosa, 2011). For a vast protected area, this amount does not suffice to sustain the conservation needs of the entire park. From the projections made by Focal Community Assistance Scheme (FOCAS), the conservation cost for the total landscape of MMRNP is roughly around PhP 21.5 million (Manlosa, 2011). This cost includes series of conservation activities particularly for upland such as reforestation, agroforestry, eco-awareness, resource utilization, etc.

The estimated mean willingness to pay from this study could be an alternative source of funds for conservation activities to meet the demands of environmental protection. The study summarizes the potential total monthly collection of conservation funds for different scenarios.

Table 7. Potential collectible using parametric estimates or MWTP for conservation activities in PhP

\begin{tabular}{cccc}
\hline SCENARIO & Monthly ('000) & Annually ('000) & After 5 years ('000) \\
\hline Mandatory & 150 & 1800 & 9000 \\
Voluntary & 118 & 1400 & 7100 \\
\hline Total \# of Hh & & $4924^{*}$ & \\
\hline
\end{tabular}

Source: * CLUP

The computed monthly collectible per scenario used the corresponding parametric and non-parametric estimates of the mean willingness to pay. The estimated values were multiplied to the number of households that would be solicited from. Also, different number of households per conservation activities as suggested in the institutional framework. Coastal conservation funds would be collected only from the coastal community.

\section{Discussion}

Overall, the people of Oroquieta City are willing to participate in conservation activities. The residents are willing to pay for additional cost of conservation if the funds collected will be managed by a well represented institution. Based from the survey, there are more female respondents $(60 \%)$ than male $(40 \%)$. Out of the total samples, $35 \%$ are unemployed, $7 \%$ rely on pensions and remittances, and the remaining are employed by the government or a company, or self employed. Around $8 \%$ of the total samples are engaged in secondary occupation.

Majority of the respondents reached secondary level (45\%) and primary level of education (24\%). On the average, the household size of the respondents consists of 4 persons per household. The average income obtained 
in the total samples is $\mathrm{PhP} 13$ 059.52.

In terms of awareness to the environment, watershed, and ecosystem services, $83 \%$ said that they are aware of Mt. Malindang Range Natural Park. Majority also knows the meaning of watershed and is also aware of different ecosystem services. However, a large fraction of the respondents experiences negative effects from upland due to farming (81\%), domestic waste (70\%), livestock raising (77\%), and quarrying $(78 \%)$

The study simulated two scenarios where the mean willingness to pay of the respondents could be generated. Scenario 1 is a representation of a mandatory collection from households and scenario 2 is a modification of the first scenario wherein only respondents who were certain with their decision to pay was computed, thus representing a voluntary collection scenario.

Factors affecting the respondents' willingness to pay in both scenarios were Bid Amount and Household size.

The study made use of both parametric and non-parametric estimation for willingness to pay. A mandatory collection estimated a mean willingness to pay of $\mathrm{PhP} 30.39$ through parametric estimation while $\mathrm{PhP} 50.81$ through non-parametric estimation.

A voluntary collection estimated a mean willingness to pay of $\mathrm{PhP} 24.01$ through parametric estimation while $\mathrm{PhP} 46.97$ via non-parametric estimation.

Majority of the reasons of the respondents who did not agree to contribute to the conservation activities is due to insufficient funds for contribution. All in all, the respondents still highly recommend the use of water bill as the payment vehicle for the collection of contributions for conservation activities.

The potential monthly collection from the community would range from PhP 118000.00 (voluntary collection) up to $\mathrm{PhP} 150000.00$ (mandatory collection). Annually, that would amount to PhP 1.4 million to PhP 1.8 million revenue. In a span of 5 years, the total collection could reach from $\mathrm{PhP} 9$ million up to $\mathrm{PhP} 7.1$ million which is very substantial for a sustainable financing of coastal conservation activities.

Generally, the residents of Oroquieta City have high awareness towards the environment and ecosystem services. The people are also aware about the implication of the activities involving extraction and destruction of natural resources. Overall, the people of Oroquieta City, with $89 \%$ of the total respondents, are willing to participate in the conservation activities.

Oroquieta city residents' high awareness to environmental conservation and willingness to pay for conservation activities could be attributed to the recent environmental disasters in neighboring provinces. The residents do not want the same disaster to happen in the area as what had happened to Iligan City and Cagayan de Oro City in the previous years. Also, a large part of Oroquieta City residents are very dependent on the ecosystems in terms of livelihood. The residents would like to continually enjoy the ecosystem services that they benefit from. Respondents who did not agree on the referendum towards additional cost on conservation activities are primarily due to income constraints. Majority of the respondents' reason $(55 \%)$ who voted no is that they cannot afford the contribution. However, if the contribution would be lower to the point where they can afford, they will also be willing to contribute eventually.

\section{Acknowledgements}

This research was accomplished with the support of United States Agency for International Development (USAID), World Agroforestry Centre (ICRAF), WorldFish Centre, and Department of Science and Technology. However, the author's view in this paper does not necessarily reflect the views of the mentioned organizations. The author would like to thank the Local Government of Oroquieta City for information shared with the study. Particularly to the City ENRO of Oroquieta City, World Agroforestry Centre (ICRAF)-Los Baños, WorldFish Centre, and UPLB - School of Environmental Science and Management for guidance and unwavering support.

\section{References}

Alli, R. A., \& Oliva, A. T. (2001). Economic Valuation for the Protection of Maasin Watershed Reservation in the Philippines. Regional Research and Development Symposia. PCARRD Highlights Journal, 131-132.

Amponin, J. A. (2008). Designing and Implementing Payments for Environmental Services: The Philippine Experience. IWLEARN Regional Workshop on Payments for Environmental Services. Hanoi, Vietnam. Retrieved

from http://iwlearn.net/abt_iwlearn/events/workshops/pes-workshop-hanoi/designing-and-implementing-payment s-for-environmental-services-the-phillippines-experience-amponin

Amponin, J. A., Bennagen, M. E. C., Hess, S., \& Dela Cruz, J. D. (2007). Willingness to Pay for Watershed 
Protection by Domestic Water Users in Tuguegarao City, Philippines. Poverty Reduction and Environmental Management (PREM) Working Paper 07/06 ASEAN Center for Biodiversity. Retrieved from http://www.prem-online.org/archive/5/doc/PREM\%20WP\%2007-06.pdf

Arin, T., \& Kramer, R. A. (2002). Diver's Willingness to Pay to Visit Marine Sanctuaries: An Exploratory Study. Ocean and Coastal Management, 45, 171-183. http://dx.doi.org/10.1016/S0964-5691(02)00049-2

Birdir, S., Unal, O., Birdir, K., \& Williams, A. (2013). Willingness to Pay as an Economic Instrument for Coastal Tourism Management: Cases from Mersin, Turkey. Tourism Management, 36, 279-283 http://dx.doi.org/10.1016/j.tourman.2012.10.020

Borges, B. (2011). Defining Payments for Ecosystem Services. Forest Trends. Retrieved from http://www.forest-trends.org/documents/files/doc_2720.pdf

Calderon, M., Camacho, L., Carandang, M., Dizon, J., Rebugio, L., \& Tolentino, N. (2005). A Water User Fee for Households in Metro Manila, Philippines. Economy and Environment Program for Southeast Asia (EEPSEA). Singapore.

Carson, R., Flores, N., \& Meade, N. (2001). Contingent Valuation: Controversies and Evidence. Environmental and Resource Economics, 19, 173-210. Kluwer Academic Publishers. Netherlands. Retrieved from http://econ.ucsd.edu/ rcarson/papers/CVcontroversies.pdf

City Government of Oroquieta. (2010). Comprehensive Land Use Plan 2010-2020. Oroquieta City, Misamis Occidental

Food and Agriculture Organization. (2012). The State of World Fisheries and Aquaculture. FAO Fisheries and Aquaculture Department. Food and Agriculture Organization of the United Nations. Rome, Italy. Retrieved from http://www.fao.org/docrep/016/i2727e/i2727e.pdf

Jabines, A., \& Inventor, J. (2007). The Philippines: A Climate Hotspot. Climate Change Impacts and the Philippines. Greenpeace Southeast Asia, Climate and Energy Campaign. Quezon City, Philippines.

Lasmarias, N. (2012). PES: Experience in Financing the Management of Philippine Uplands and Forest. Conversations in Conservation: PES and New Frontiers in Sustainable Financing. Crowne Plaza Hotel, Manila.

Retrieved

from http://sites3.iwlearn3.webfactional.com/cti/knowledge-hub/document-library/payment-for-ecosystem-servic es-pes/pes-readings/NoelaLasmarias_PESforTerrestrial.pdf

Manlosa, A. (2011). Environmental Benefits and Costs of Conserving Layawan Watershed for Sustainable Domestic Water Supply in Oroquieta City, Philippines. (unpublished Master of Science Thesis). University of the Philippines-Los Baños. Laguna, Philippines.

Padilla, J., Tongson, E., \& Lasco, R. (2005). PES: Sustainable Financing for Conservation and Development. Proceedings from the National Conference-Workshop on Payments for Environment Services: Direct Incentives for Biodiversity Conservation and Poverty Alleviation. Manila, March 1-2, 2005.

Samonte-Tan, G. P. B., White, A., Tercero, M. A., Diviva, J., Tabara, E., \& Caballes, C. (2007). Economic Valuation of Coastal and Marine Resources: Bohol Marine Triangle, Philippines. Coastal Management, 35, 319-338. http://dx.doi.org/10.1080/08920750601169634

Virola, R. A. (2011). 2009 Official Poverty Statistics. National Statistical Coordination Board. NSCB Operations Room, Makati City. Retrieved from http://www.focusonpoverty.org/download/data/2009\%20Poverty\%20Statistics\%20(NSCB).pdf

Wedgwood, A., \& Sansom, K. (2003). Willingness-to-pay surveys- A streamlined approach: Guidance notes for small town water services. WEDC, Loughborough University. UK. Retrieved from http://www.partnershipsforwater.net/psp/tc/TC_Tools/006T_Willingness\%20to\%20pay.pdf

Wunder, S. (2005). Payments for environmental services: Some nuts and bolts. CIFOR Occasional Paper No. 42. Center for International Forestry Research. Jakarta, Indonesia.

\section{Copyrights}

Copyright for this article is retained by the author(s), with first publication rights granted to the journal.

This is an open-access article distributed under the terms and conditions of the Creative Commons Attribution license (http://creativecommons.org/licenses/by/3.0/). 